\title{
Influence of chemical seed dressing on efficacy of pea seed inoculation with root-nodule bacteria
}

\section{Oddziaływanie zaprawy chemicznej na efektywność szczepienia nasion grochu bakteriami brodawkowymi}

\author{
Stefan Martyniuk, Monika Kozieł, Anna Gałązka
}

\begin{abstract}
Summary
Chemical seed dressings as biologically active substances can adversely affect the survival of root-nodule bacteria inoculated onto legume seeds and thereby reduce the number of symbiotic nodules, and thus decrease the efficacy of the whole symbiotic process. In the pot experiments the effect of chemical seed dressing Vitavax 200 FS on nodulation and growth of two field pea cultivars: Cud Kalvedonu and Grapis was studied. Untreated and Vitavax 200 FS treated pea seeds were pelleted with inoculant containing symbiotic bacteria (Rhizobium leguminosarum bv. viciae) and sown into pots filled with perlite moistened with water solution of plant nutrients (without N). The inoculated with bacteria seeds were sown within 1-2 hours or 24 hours after storing at room temperature. After 4 weeks of growing plants in a growth chamber a number of root nodules was counted and fresh and dry mass of shoots were measured. The studied chemical seed dressing had no significant effect on nodulation and growth of both pea cultivars but only when seeds were sown directly after their inoculation with the symbiotic bacteria. Vitavax $200 \mathrm{FS}$ affected negatively nodulation and plant growth when the treated seeds were sown 24 hours following the inoculation with symbiotic bacteria.
\end{abstract}

Key words: pea; root-nodule bacteria; symbiosis; inoculation; chemical seed dressing

\section{Streszczenie}

Zaprawy chemiczne jako substancje biologicznie aktywne mogą wpływać niekorzystnie na przeżywalność bakterii brodawkowych wprowadzonych na nasiona, a tym samym na efektywność całego procesu symbiozy. W doświadczeniach wazonowych badano wpływ zaprawy Vitavax 200 FS na brodawkowanie i wzrost siewek dwóch odmian grochu siewnego Cud Kalvedonu i Grapis. Niezaprawione (kontrolne) i zaprawione preparatem Vitavax 200 FS nasiona badanych odmian zaszczepiono szczepionką zawierającą bakterie symbiotyczne grochu (Rhizobium leguminosarum bv. viciae) i wysiano do wazonów z perlitem uwilgotnionym pożywką mineralną (bez $\mathrm{N})$ dla roślin. Nasiona wysiewano bezpośrednio po ich zaszczepieniu bakteriami symbiotycznymi oraz po 24-godzinnym przechowywaniu zaszczepionych nasion w temperaturze pokojowej. Po 4 tygodniach wzrostu w komorze fitotronowej oznaczono liczbę brodawek na korzeniach oraz świeżą i suchą masę roślin grochu. Nie stwierdzono istotnego wpływu badanej zaprawy chemicznej na liczbę brodawek na korzeniach i wzrost roślin grochu, ale tylko wtedy, gdy nasiona wysiano bezpośrednio po zaszczepieniu ich bakteriami symbiotycznymi. Zaprawa Vitavax 200 FS miała jednak niekorzystny wpływ na brodawkowanie grochu, jeżeli zaprawione i zaszczepione bakteriami nasiona wysiano po 24-godzinnym ich przechowywaniu w temperaturze pokojowej.

Słowa kluczowe: groch; bakterie brodawkowe; symbioza; szczepienie; zaprawa chemiczna

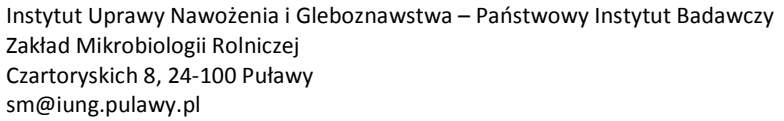




\section{Wstęp / Introduction}

Przedsiewne zaprawianie nasion preparatami chemicznymi jest jednym $\mathrm{z}$ podstawowych zabiegów w nowoczesnej agrotechnice wielu roślin, w tym także strączkowych (Księżak i wsp. 1995; Podleśny i Brzózka 2001; Kutcher i wsp. 2002; Graham i Vance 2003). Zaprawy nasienne (fungicydy i insektycydy) ograniczają bowiem rozwój patogenów i szkodników nie tylko w czasie kiełkowania nasion, ale także w początkowych fazach rozwoju młodych siewek roślin. W przypadku uprawy roślin strączkowych (i innych motylkowatych) ważne jest również stosowanie szczepionek zawierających bakterie symbiotyczne (Rhizobium, Bradyrhizobium, Sinorhizobium) tych roślin. Wymienione bakterie przyczyniają się do powstawania na korzeniach roślin motylkowatych brodawek symbiotycznych, w których następuje redukcja (wiązania) azotu atmosferycznego do formy amonowej, przyswajalnej dla roślin (Graham i Vance 2003; Martyniuk 2012). Stosowanie szczepionek rizobiowych na ogół powoduje istotne zwyżki plonów roślin motylkowatych, zwłaszcza wtedy, gdy w glebie brak jest bakterii symbiotycznych, lub gdy liczebność tych bakterii w środowisku glebowym jest niska, np. na skutek wieloletniej przerwy w uprawie omawianych roślin lub nadmiernego zakwaszenia gleby (Rennie i Dubetz 1984; Kutcher i wsp. 2002). Preparaty szczepionkowe zawierające bakterie symbiotyczne stosowane są najczęściej na nasiona roślin motylkowatych, które powinny być także zaprawiane preparatami chemicznymi. Jednak niektóre substancje czynne zapraw nasiennych, np. mankozeb, niekorzystnie wpływają na przeżywalność bakterii brodawkowych wprowadzonych na nasiona, a tym samym zmniejszają liczbę zawiązywanych brodawek na korzeniachi efektywność całego procesu symbiozy tych bakterii z roślinami motylkowatymi (Martyniuk i wsp. 2000, 2002).

Celem badań było poznanie wpływu zaprawy nasiennej Vitavax 200 FS na efektywność szczepienia nasion grochu (Pisum sativum L) bakteriami symbiotycznymi (Rhizobium leguminosarum biovar viciae) w doświadczeniach wazonowych.

\section{Materiały i metody / Materials and methods}

\section{Materiały}

W przeprowadzonych doświadczeniach użyto nasion dwóch odmian grochu Cud Kalvedonu oraz Grapis, w stopniu odsiewu - oryginał. Do zaszczepiania nasion użyto przygotowanego w Zakładzie Mikrobiologii Instytutu Uprawy Nawożenia i Gleboznawstwa - Państwowego Instytutu Badawczego, preparatu szczepionkowego zawierającego dwa szczepy bakterii symbiotycznych grochu (Rh. leguminosarum bv. viciae) GGL i PGK. Materiałem nośnikowym w tym preparacie był wyjałowiony pył węgla brunatnego (taki sam jak w preparatach handlowych) zaszczepiony czystymi kulturami wymienionych szczepów bakterii symbiotycznych grochu. W 1 gra- mie tak przygotowanej szczepionki znajdowało się około $3 \times 10^{10}$ komórek bakterii symbiotycznych. Szczepionkę zastosowano w dawce $10 \mathrm{~g} / \mathrm{kg}$ nasion metodą „na mokro", czyli odważoną porcję szczepionki wymieszano $\mathrm{z}$ wodą w stosunku 1:1 (w/w) i uzyskaną w ten sposób zawiesiną otoczkowano nasiona.

Użyta w badaniach zaprawa nasienna Vitavax 200 FS zawiera w swoim składzie karboksynę $(20 \%)$ i tiuram (20\%) jako substancje czynne o działaniu grzybobójczym. Środek ten jest zarejestrowany do zaprawiania przede wszystkim ziarna zbóż oraz nasion roślin strączkowych, takich jak łubin i groch. W przypadku grochu zlecana przez producenta dawka na $100 \mathrm{~kg}$ nasion wynosi $400 \mathrm{ml}$ zaprawy, najlepiej rozcieńczonej wodą w stosunku 1:1.

\section{Metodyka}

Niezaprawione i zaprawione poprzedniego dnia preparatem Vitavax 200 FS nasiona badanych odmian grochu zaszczepiono bakteriami brodawkowymi i wysiano do wazonów $(500 \mathrm{ml})$ wypełnionych perlitem uwilgotnionym $50 \mathrm{ml}$ pożywki mineralnej (bez $\mathrm{N}$ ) dla roślin. Nasiona wysiewano bezpośrednio, tzn. w ciągu 1-2 godzin po zastosowaniu szczepionki mikrobiologicznej oraz po 24 godzinach od wykonania tego zabiegu. Zaszczepione bakteriami nasiona grochu przechowywano przez 24 godziny $\mathrm{w}$ temperaturze pokojowej $\left(20-22^{\circ} \mathrm{C}\right)$. Przeprowadzono cztery doświadczenia wazonowe $\mathrm{w}$ fitotronie, po dwa z każdą odmianą grochu. Do wazonów wysiano po pięć nasion, a po wschodach zredukowano liczbę siewek do 4 (Cud Kalvedonu) lub 3 (Grapis). Po upływie 4 tygodni policzono liczbę brodawek na korzeniach każdej rośliny oraz oznaczono świeżą i sucha masę pędów oraz suchą masę korzeni. Co 2 dni rośliny w wazonach podlewano $10 \mathrm{ml}$ jałowej wody. Każde doświadczenie składało się z trzech obiektów, czyli: I - nasiona niezaprawiane preparatem chemicznym, ale zaszczepione bakteriami symbiotycznymi $(-\mathrm{V}+\mathrm{BS})$, II - nasiona zaprawione i zaszczepione bakteriami $(+\mathrm{V}+\mathrm{BS})$, III - nasiona $+\mathrm{V}+\mathrm{BS}$ wysiane po $24 \mathrm{~h}$ od zastosowania szczepionki bakteryjnej. W każdym obiekcie zastosowano po trzy powtórzenia (wazony), a przedstawione w tabeli wyniki są średnimi z dwóch doświadczeń dla obydwu badanych odmian grochu. Uzyskane wyniki analizowano statystycznie, a istotność różnić oceniano za pomocą testu Tukeya na poziomie istotności $5 \%$.

\section{Wyniki i dyskusja / Results and discussion}

$\mathrm{Na}$ korzeniach roślin obydwu odmian grochu wyrosłych z nasion zaprawionych Vitavax 200 FS i wysianych bezpośrednio po zastosowaniu szczepionki bakteryjnej (obiekt II) stwierdzono mniej brodawek niż na korzeniach roślin w obiekcie I, czyli wyrosłych z nasion niezaprawianych chemicznie (tab. 1,2), ale różnice te nie były istotne statystycznie. Ze względu na to, że pożywka mineralna użyta do uwilgotnienia podłoża (perlitu) nie 
Tabela 1. Oddziaływanie zaprawy nasiennej Vitavax 200 FS na efektywność szczepienia nasion grochu (odmiana Cud Kalvedonu) bakteriami symbiotycznymi

Table 1. Influence of seed-applied Vitavax 200 FS on efficacy of pea (cultivar Cud Kalvedonu) seed inoculation with symbiotic bacteria

\begin{tabular}{l|c|c|c|c}
\hline $\begin{array}{c}\text { Obiekt } \\
\text { Treatment }\end{array}$ & $\begin{array}{c}\text { Liczba brodawek/roślinę } \\
\text { Number } \\
\text { of nodules/plant }\end{array}$ & $\begin{array}{c}\text { Świeża masa pędów [g]/ } \\
\text { wazon } \\
\text { Fresh weight of shoots } \\
{[\mathrm{g}] / \mathrm{pot}}\end{array}$ & $\begin{array}{c}\text { Sucha masa pędów [g]/ } \\
\text { wazon } \\
\text { Dry weight of shoots } \\
{[\mathrm{g}] / \mathrm{pot}}\end{array}$ & $\begin{array}{c}\text { Sucha masa korzeni [g]/ } \\
\text { wazon } \\
\text { Dry weight of roots } \\
{[\mathrm{g}] / \text { pot }}\end{array}$ \\
\hline $\mathrm{I} \mathrm{(-V+BS)*}$ & $64,0 \mathrm{a}$ & $5,9 \mathrm{a}$ & $0,85 \mathrm{a}$ & $0,33 \mathrm{a}$ \\
\hline $\mathrm{II}(+\mathrm{V}+\mathrm{BS})$ & $54,0 \mathrm{a}$ & $5,3 \mathrm{ab}$ & $0,72 \mathrm{ab}$ & $0,31 \mathrm{a}$ \\
\hline $\mathrm{III}(+\mathrm{V}+\mathrm{BS})-24$ & $5,0 \mathrm{~b}$ & $4,4 \mathrm{~b}$ & $0,62 \mathrm{~b}$ & $0,37 \mathrm{a}$ \\
\hline
\end{tabular}

*I - nasiona niezaprawione Vitavax 200 FS i zaszczepione - seeds untreated with Vitavax 200 FS but inoculated; II - nasiona zaprawione i zaszczepione - seed treated with Vitavax 200 FS and inoculated; III - nasiona jak w II wysiane po $24 \mathrm{~h}$ - seeds as in II planted after $24 \mathrm{~h}$

Tabela 2. Oddziaływanie zaprawy nasiennej Vitavax 200 FS na efektywność szczepienia nasion grochu (odmiana Grapis) bakteriami symbiotycznymi

Table 2. Influence of seed-applied Vitavax 200 FS on efficacy of pea (cultivar Grapis) seed inoculation with symbiotic bacteria

\begin{tabular}{l|c|c|c|c}
\hline $\begin{array}{c}\text { Obiekt } \\
\text { Treatment }\end{array}$ & $\begin{array}{c}\text { Liczba brodawek/ roślinę } \\
\text { Nodule number/plant }\end{array}$ & $\begin{array}{c}\text { Świeża masa pędów } \\
{[\mathrm{g}] / \text { wazon }} \\
\text { Fresh weight of shoots } \\
{[\mathrm{g}] / \mathrm{pot}}\end{array}$ & $\begin{array}{c}\text { Sucha masa pędów } \\
{[\mathrm{g}] / \text { wazon }} \\
\text { Dry weight of shoots } \\
{[\mathrm{g}] / \mathrm{pot}}\end{array}$ & $\begin{array}{c}\text { Sucha masa korzeni } \\
{[\mathrm{g}] / \text { wazon }} \\
\text { Dry weight of roots } \\
{[\mathrm{g}] / \mathrm{pot}}\end{array}$ \\
\hline $\mathrm{I}(-\mathrm{V}+\mathrm{BS})^{*}$ & $42,0 \mathrm{a}$ & $3,0 \mathrm{a}$ & $0,42 \mathrm{a}$ & $0,26 \mathrm{a}$ \\
\hline $\mathrm{II}(+\mathrm{V}+\mathrm{BS})$ & $31,0 \mathrm{a}$ & $2,6 \mathrm{ab}$ & $0,36 \mathrm{ab}$ & $0,23 \mathrm{a}$ \\
\hline $\mathrm{III}(+\mathrm{V}+\mathrm{BS})-24$ & $5,2 \mathrm{~b}$ & $2,4 \mathrm{~b}$ & $0,33 \mathrm{~b}$ & $0,28 \mathrm{a}$ \\
\hline
\end{tabular}

*I - nasiona niezaprawione Vitavax 200 FS i zaszczepione - seeds untreated with Vitavax 200 FS but inoculated; II - nasiona zaprawione i zaszczepione - seed treated with Vitavax 200 FS and inoculated; III - nasiona jak w II wysiane po $24 \mathrm{~h}-$ seeds as in II planted after $24 \mathrm{~h}$

zawierała azotu mineralnego, słabsze brodawkowanie, a więc i słabsze zaopatrzenie roślin grochu $\mathrm{w}$ azot związany symbiotycznie w obiekcie II (z Vitavax 200 FS spowodowało, że świeża i sucha masa pędów grochu w tym obiekcie były niższe niż w obiekcie I (bez Vitavax 200 FS (tab. 1, 2). Podobnie jak w przypadku brodawkowania, stwierdzone różnice w biomasie pędów obydwu odmian grochu w obiektach I i II, nie były istotne statystycznie. Jednak, kiedy zaprawione i zaszczepione nasiona badanych odmian grochu wysiano po 24-godzinnym ich przechowywaniu $\mathrm{w}$ temperaturze otoczenia (20-22 $\left.{ }^{\circ} \mathrm{C}\right)$, rośliny wyrosłe $\mathrm{z}$ tych nasion (obiekt III) charakteryzowały się dużo mniejszą liczebnością brodawek na korzeniach niż rośliny wyrosłe z nasion wysianych bezpośrednio po zastosowaniu szczepionki (obiekty I i II). Także wzrost roślin był najsłabszy w obiekcie III, a świeża i sucha masa pędów grochu w tym obiekcie była istotnie niższa niż w obiekcie I, w którym nasiona nie zaprawiono preparatem Vitavax 200 FS (tab. 1, 2). W warunkach przeprowadzonych doświadczeń wazonowych zaprawa Vitavax 200 FS nie różnicowała istotnie wielkości (sucha masa) systemów korzeniowych obydwu odmian grochu (tab. 1, 2). Przeprowadzone doświadczenia wskazują wyraźnie, że zaprawionych chemicznie i zaszczepionych bakteriami symbiotycznymi nasion grochu nie należy przechowywać, lecz wysiewać możliwie jak najszybciej po zastosowaniu szczepionki bakteryjnej. We wcześniejszych badaniach wykazano, że przechowywanie nasion zaszczepionych preparatami mikrobiologicznymi powoduje zamieranie bakterii na wysychających nasionach, nawet wtedy, gdy zaszczepione nasiona nie były wcześniej zaprawione preparatami chemicznymi (Rennie i Dubetz 1984; Martyniuk i wsp. 2000, 2002). Możliwie jak najszybsze wysianie zaszczepionych bakteriami symbiotycznymi nasion powoduje, że w glebie (lub innym podłożu) nasiona nie wysychają, a ponadto część $\mathrm{z}$ wprowadzonych wraz $\mathrm{z}$ nasionami bakterii brodawkowych przedostaje się do gleby otaczającej nasiona $\mathrm{i}$ w ten sposób są mniej narażone na szkodliwe oddziaływania zapraw chemicznych.

Pomimo, że Vitavax 200 FS zarejestrowany jest jako zaprawa nasienna do ochrony grochu, jego wpływ na proces symbiozy tej rośliny $\mathrm{z}$ bakteriami brodawkowymi wprowadzanymi na nasiona, nie był dotychczas badany w naszym kraju. Wyniki przeprowadzonych badań, podobnie jak te uzyskane we wcześniejszych doświadczeniach z zaprawami zawierającymi w swoim składzie takie substancje aktywne jak karbosulfan (insektycyd) lub tiuram i karbendazym (Martyniuk i wsp. 2000, 2002; Kutcher i wsp. 2002), są ważne zwłaszcza w aspekcie praktycznym. Wskazują, jak należy postępować jeżeli przedsiewnie nasiona roślin strączkowych zaprawiane są preparatami chemicznymi i mikrobiologicznymi, zwierającymi bakterie symbiotyczne tych roślin. 


\section{Wniosek / Conclusion}

Zaprawa nasienna Vitavax 200 FS nie wpływa ujemnie na efekty szczepienia nasion grochu bakteriami brodawkowymi, ale zaprawione i zaszczepione nasiona naleyż wysiewać możliwie jak najszybciej po zastosowaniu szczepionki bakteryjnej.

\section{Literatura / References}

Graham P.H., Vance C.P. 2003. Legumes: importance and constrains to greater use. Plant Physiol. 131: 872-877.

Księżak J., Podleśny J., Brzózka F. 1995. Technologia produkcji nasion grochu i ich wykorzystanie w żywieniu zwierząt. Instrukcja upowszechnieniowa IUNG - PIB 52/95, 21 ss.

Kutcher H.R., Lafond G., Johnston A.M., Miller P.R., Gill K.S., May W.E., Hogg T., Johnson E., Biederbeck V.O., Nybo B. 2002. Rhizobium inoculants and seed-applied fungicide effects on field pea production. Can. J. Plant Sci. 82: 645-651.

Martyniuk M., Oroń J., Woźniakowska A., Martyniuk S. 2000. Oddziaływanie zapraw chemicznych na przeżywalność bakterii brodawkowych na nasionach bobiku oraz na proces symbiozy. Pam. Puł. 121: 41-47.

Martyniuk S., Oroń J., Martyniuk M., Woźniakowska A. 2002. Effects of interactions between chemical seed dressings and Bradyrhizobium japonicum on soybean seeds. Arch. Acker-Pfl. Boden. 48: 305-310.

Martyniuk S. 2012. Naukowe i praktyczne aspekty symbiozy roślin strączkowych z bakteriami brodawkowymi. Pol. J. Agron. 9: 17-22.

Podleśny J., Brzóska F. 2001. Uprawa łubinu żółtego na nasiona i wykorzystanie ich w żywieniu zwierząt. Instrukcja upowszechnieniowa IUNG - PIB 76/01, 35 ss.

Rennie R.J., Dubetz S. 1984. Effect of fungicides and herbicides on nodulation and $\mathrm{N}_{2}$ fixation in soybean fields lacking indigenous Rhizobium japonicum. Agron. J. 76 (3): 451-454. 